\title{
An Efficient Method for Production of Extracellular Human Tissue Factor in Escherichia coli
}

\author{
Hwan Goo Yoo, Yang Jin Park and Woo-Yiel Lee ${ }^{1}$ * \\ Department of Chemistry, ${ }^{1}$ Department of Pharmaceutical Engineering, Konyang University, Nonsan, ChungNam 320-711, Korea \\ Received February 18, 2009 /Accepted April 20, 2009
}

\begin{abstract}
Human Tissue factor is an essential enzyme activator that forms a catalytic complex with factor VII/ VIIa, and catalyzes both the extrinsic and intrinsic blood coagulation cascades. The extracellular domain of human tissue factor is responsible for association with the biological partner. The efficient procedures for preparing biologically active human tissue factor are essential for the preclinical and clinical studies with coaguligands. An expression vector in Escherichia coli has been constructed to direct the production of extracellular human tissue factor without a fusion protein or a $\mathrm{His}_{6}$ at the $\mathrm{N}$-terminus. The recombinant human tissue factor was expressed in large amounts as a non-native state in E. coli. The recombinant protein was simply renatured during the DEAE-sephacel chromatographic purification procedure. Our expression and purification system does not require a protease treatment or an additional chromatographic step to remove a fusion contaminant, which provides a very useful alternative to conventional expression systems for the production of human tissue factor.
\end{abstract}

Key words : Extracellular domain, expression system, human tissue factor, purification, refolding

\section{Introduction}

Blood coagulation is initiated by the complex of tissue factor (TF) and coagulation factor VIIa (FVIIa) which has a proteolytic activity [4]. The complex ensures normal haemostasis but is also involved in the pathogenesis of different disease processes, such as septic shock, thrombotic vascular disease, and cancer metastasis [5]. TF is a membrane bound glycoprotein which consists of three distinct domains: an extracellular domain (1-219), a hydrophobic transmembrane region (220-242), and a cytoplasmic tail (243-263) [6]. The extracellular domain containing two disulfide bonds is responsible for the forming a complex with FVII or FVIIa and for the proteolytic activation of factor IX and X [8]. Several strategies have been employed for the expression of human TF. A truncated form of TF (tTF), consisting of the $\mathrm{ex}^{-}$ tracellular domain, has been expressed in a non-native state in E. coli inclusion bodies as a fusion protein with polyhistidine residues at the $\mathrm{N}$-terminus [7]. The study to sim- $^{-}$ plify the procedures including the renaturation and purification of recombinant tTF in E. coli has been carried out by introducing on-column refolding method, in which the recombinant protein has been refolded while immobilized on $\mathrm{Ni}^{2+}$-nitriloacetic acid (NTA) column [2]. Recently, the fusion

*Corresponding author

Tel : +82-41-730-5694, Fax : +82-41-730-5762

E-mail : lee0519@konyang.ac.kr system with maltose binding protein has been described to improve the yield and easy of purification of recombinant tTF [3]. A major drawback of these approaches is that an enzymatic cleavage and an additional purification step for removing the contaminants resulted from the enzymatic treatment must be applied to purify the recombinant tTF as a biologically active form, which are time-consuming and high-cost procedures.

The efficient procedure for preparing the large quantities of recombinant TF is necessary for the production of medical proteins or other industrial proteins. In this report, we describe an efficient preparation of the catalytic domain of human TF from a new E. coli expression system without a fusion protein or $\mathrm{His}_{6} \mathrm{tag}$, which does not require the procedure of an enzymatic cleavage and the additional chromatographic step.

\section{Materials and Methods}

\section{Construction of a recombinant plasmid pRX-tTF}

An expression vector was constructed from pRX, a derivative of pRSET (Invitrogen, Carlsbad, CA), in which six His, epitope, and enterokinase cleavage site were removed. The cDNA coding for human TF was amplified by polymerase chain reaction (PCR) using the primers (GenoTech, Deaduk, Korea) 5'-CGGGATCCGGCACTACAAATACTGT (5' primer) and 5'-TGTAAGCTTATTCTCTGAATTCCCCTT 
(3' primer) containing a BamHI and a HindIII restriction site (indicated by underline), respectively. The PCR product was cloned into pRX digested by BamHI/HindIII, generating plasmid pRX-tTF. The deduced amino acid sequence of the clone contains the authentic sequence (residues 1-219) of the extracellular domain of human TF. Taq DNA polymerase, DNA ligase, and restriction enzymes were purchased from Promega (Seoulin Bioscience, Seoul, Korea). The N-terminal sequencing of proteins was performed by Edman degradation (Korea Basic Science Institute, Daejeon, Korea). All other chemicals were purchased from commercial sources and were specific grade or first grade reagents.

\section{Expression of recombinant tTF in E. coli}

The E. coli strain BL21 (DE3) (Novagen, Darmstadt, Germany) was transformed with the resulting plasmid carrying tTF DNA. Single colonies were grown at $37^{\circ} \mathrm{C}$ in $\mathrm{LB}$ medium (500 ml) containing $100 \mu \mathrm{g} / \mathrm{ml}$ ampicilin. When the absorbance at $595 \mathrm{~nm}$ reached about $0.5,0.5 \mathrm{ml}$ of $1 \mathrm{M}^{\text {iso- }}$ propyl $\beta$-D-thiogalactopyranoside (IPTG) was added. The culture was shaken overnight at $37^{\circ} \mathrm{C}$ at $250 \mathrm{rpm}$. The cells were harvested by centrifugation at 10,000 $\times \mathrm{g}$ for $20 \mathrm{~min}$. SDS-PAGE was performed on $12 \%$ polyacrylamide gels for the analysis of proteins.

The cell (4.5 g wet weight) was washed with $100 \mathrm{ml}$ of $10 \mathrm{mM}$ Tris- $\mathrm{HCl}$ buffer (pH 7.5) containing 20\% sucrose and $1 \mathrm{mM}$ EDTA. The cells were resuspended in $100 \mathrm{ml}$ of Tris- $\mathrm{HCl}$ buffer (pH 7.5) containing $250 \mathrm{mM} \mathrm{NaCl}, 1 \%$ Triton $\mathrm{X}-100$, $1 \mathrm{mg}$ lysozyme (Sigma, Saint Louis, MO), $1 \mathrm{mM} \mathrm{MgCl} 2$ and $1 \mathrm{mM}$ EDTA, and disrupted by sonication. The mixture was stirred gently for $1 \mathrm{hr}$ at $4^{\circ} \mathrm{C}$ and centrifuged at $10,000 \times$ $g$ for $20 \mathrm{~min}$. The pellet paste was washed twice with water. The pellet were resuspended in $50 \mathrm{ml}$ of Tris- $\mathrm{HCl}$ buffer $(\mathrm{pH}$ 7.5) containing $50 \mathrm{mM} \mathrm{NaCl}$ and $1 \%$ Triton $\mathrm{X}-100$, agitated by stirring for $1 \mathrm{~h}$ at $4^{\circ} \mathrm{C}$, and centrifuged at $10,000 \times g$ for $20 \mathrm{~min}$. This procedure was repeated by two times. The final pellet was the highly enriched inclusion bodies of recombinant $\mathrm{tTF}$.

\section{Purification of the recombinant tTF.}

The inclusion bodies of recombinant tTF were resuspended in $100 \mathrm{ml}$ of buffer S (6 M urea, $10 \mathrm{mM}$ Tris-HCl, $\mathrm{pH}$ 8.0). The solution was stirred for $1 \mathrm{hr}$ and centrifuged at $30,000 \times g$ for $30 \mathrm{~min}$ at $4^{\circ} \mathrm{C}$. The supernatant was loaded onto $100 \mathrm{ml}$ DEAE-Sephacel column which had been equilibrated with buffer S. The column was washed with $100 \mathrm{ml}$ of buffer $\mathrm{S}$ and then with a linear gradient solution from $6 \mathrm{M}$ to $0 \mathrm{M}$ urea $(200 \mathrm{ml}$ each) in $10 \mathrm{mM}$ Tris- $\mathrm{HCl}$ buffer (3 mM GSH, $1 \mathrm{mM}$ GSSG, $0.02 \% \mathrm{NaN}_{3}$, $\mathrm{pH}$ 8.0) for refolding recombinant protein. The refolding procedure was performed for 3-5 hr. Elution was carried out with a gradient of $0-1.0 \mathrm{M} \mathrm{NaCl}$ in $10 \mathrm{mM}$ Tris- $\mathrm{HCl}$ buffer (pH 7.5). A flow rate of $3 \mathrm{ml} / \mathrm{min}$ was performed and the protein was monitored by absorbance at $280 \mathrm{~nm}$. The eluted protein solution was concentrated using Amicon (Millipore, Billerica, MA) with YM-10 filter, and dialyzed against $50 \mathrm{mM}$ Tris- $\mathrm{HCl}$ buffer ( $\mathrm{pH}$ 7.5). The protein concentration was determined by Bradford method with bovine serum albumin as standard protein [1].

\section{Activity assay of recombinant tTF}

The catalytic activity of the refolded tTF was assayed using a peptidyl chromogenic substrate, Spectrozyme FXa, $\left(\mathrm{MeO}^{-}\right.$ CO-D-CHG-Gly-Arg-pNA.AcOH, American Diagnostica, Greenwich, CT), as previously described [4]. A commercially available TF (designated as standard tTF, provided by Dr. Lee at ATGene Research Institute, Daeduk, Korea) was used for the comparison with the recombinant tTF. In a microtiter plate, tTF was incubated at room temperature for $10 \mathrm{~min}$ with $0.1 \mu \mathrm{M}$ of FVIIa (Novo Nordisk, Bagsværd, Denmark) in Tris- $\mathrm{HCl}$ buffer (pH 7.5) containing $5 \mathrm{mM} \mathrm{CaCl} 2$ and $0.1 \%$ Bovine serum albumin (BSA). Spectrozyme FXa was added to the assayed mixture at a final concentration of $0.5 \mathrm{mM}$ and the catalytic activity was determined by measuring the increase in absorbance of the free pNA generated per min at $405 \mathrm{~nm}$. One unit of the activity was defined as the amount of protein to produce an increase of 0.1 O.D in absorbance at $405 \mathrm{~nm}$.

\section{Results}

\section{Expression of recombinant TF in E. coli.}

An expression vector, pRX-tTF (Fig. 1), encoding the extracellular Human TF was constructed from pRSET vector. The plasmid does not have a fusion protein or His 6 tag, and carries the authentic sequence (residues 1-219) of the catalytic domain of human TF except for having extra methionine and glycine residues in front of the $\mathrm{N}$-terminal serine. The stop codon (TAA) was included in the 3'-primer so that the $\mathrm{C}$-terminus of tTF protein should be glutamic acid which is the C-terminal residue of the genuine extracellular domain. The $\mathrm{N}$-terminal sequence of the expressed tTF was 


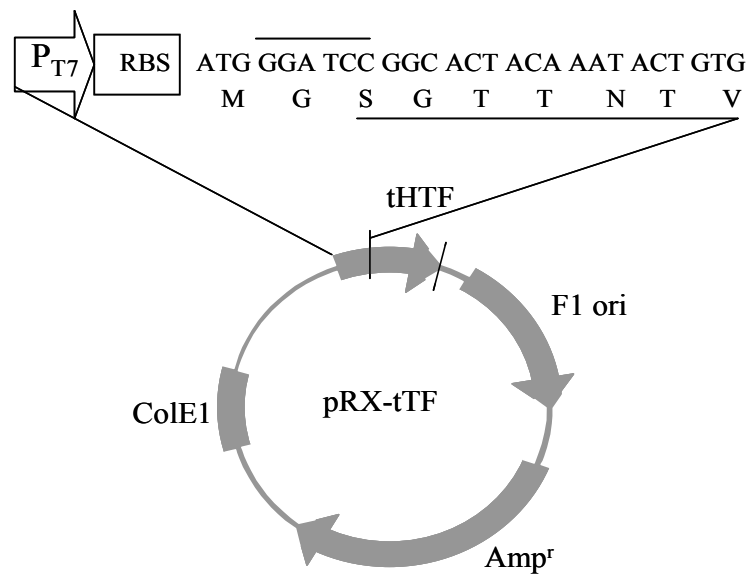

Fig. 1. Expression vector pRX-tTF. The first line is the coding sequence showing the starting codon and BamHI site (indicated by overline) at the N-terminus of tTF. The second line is the translated amino acid sequence for this region. The underline indicates the amino acid sequence of the cDNA of tTF.

demonstrated to have the expected sequence by Edman degradation. The expression of the tTF was induced by IPTG at $1 \mathrm{mM}$. The recombinant tTF was expressed in large quantity in the transformed E. coli. SDS-PAGE analysis of the cultured cells revealed a predominant protein with an apparent molecular size of about $30 \mathrm{kDa}$ (Data not shown).

\section{Purification and renaturation of tTF}

The majority of the tTF was produced in inclusion bodies in aggregated form. Since the physical and chemical properties of the insoluble aggregates in the inclusion bodies are distinct from those of the endogenous proteins of the host, their purification has been facilitated. The inclusion bodies were carefully isolated by repeated washing. The recombinant tTF in non-native state was highly purified by DEAE-Sephacel column chromatography. The refolding of the recombinant protein was carried out on the column by running a linear gradient of $6 \mathrm{M}-0$ M Urea. Elution was carried out with a gradient of $0-1.0 \mathrm{M} \mathrm{NaCl}$. Fractions containing the amidolytic activity in presence of FVIIa, which showed one sharp peak, were collected (Fig. 2). Yields after the column were 30-50 mg per one liter of cell culture (Table 1). The purity of the tTF is comparable to that of standard tTF as judged by SDS-PAGE analysis (Fig. 3). The slower movement of standard tTF (Fig. 3, lane 2) suggests that its commercial form may not be completely denatured, or may be slightly larger than the recombinant in real size.

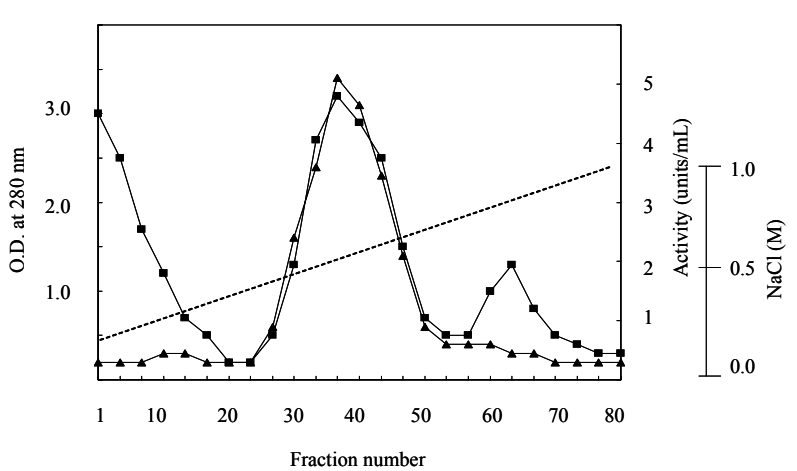

Fig. 2. DEAE-Sephacel column chromatogram. Elution was carried out with a gradient of $0-1.0 \mathrm{M} \mathrm{NaCl}$ in $10 \mathrm{mM}$ Tris-HCl buffer (pH 7.5). Symbols: ------, $\mathrm{NaCl}$ gradient;

$\mathbf{\square}$, O.D. at $280 \mathrm{~nm}, \mathbf{\Delta}$, the amidolytic activity in presence of FVIIa.

Table 1. Purification of recombinant tTF based on one liter E. coli culture

\begin{tabular}{lrcc}
\hline & $\begin{array}{c}\text { Protein } \\
(\mathrm{mg})\end{array}$ & $\begin{array}{c}\text { Total } \\
\text { activity } \\
(\mathrm{U})\end{array}$ & $\begin{array}{c}\text { Specific } \\
\text { Activity } \\
(\mathrm{U} / \mathrm{mg})\end{array}$ \\
\hline Cell lysates $^{\mathrm{a}}$ & 3220 & $\mathrm{ND}^{\mathrm{a}}$ & \\
Isolated Inclusion bodies $^{\mathrm{b}}$ & 270 & 221 & 0.82 \\
DEAE-Sephacel & 43 & 170 & 3.90 \\
\hline
\end{tabular}

${ }^{\mathrm{a}}$ Not determined

${ }^{\mathrm{b}}$ The inclusion bodies was refolded before measuring the activity: The highly enriched inclusion bodies were solubilized in buffer ( $\mathrm{pH}$ 8.0) containing $6 \mathrm{M}$ guanidinium chloride, $0.5 \mathrm{M}$ $\mathrm{NaCl}$, and $20 \mathrm{mM}$ Tris- $\mathrm{HCl}$ by gentle stirring for $4 \mathrm{~h}$ at room temperature. The refolding of recombinant tTF was accomplished by modified procedures based on the previously $\mathrm{de}^{-}$ scribed method [7].

\section{Verification of activity of purified recombinant tTF}

The catalytic activity of the recombinant tTF prepared in this study was compared with a standard tTF. The hydrolysis activity of FVIIa toward chromogenic substrate Spectrozyme FXa was investigated over a range of concentrations of tTF between $1 \mathrm{nM}$ and $10 \mu \mathrm{M}$. The assay was accomplished in the presence of $0.1 \mu \mathrm{M}$ of FVIIa. The tTF obtained in this study was not distinguishable from the standard tTF (Fig. 4).

\section{Discussion}

We have developed a new expression system without a fusion partner or polyhistidine tag which produces tTF at high level in E. coli and have shown that the recombinant protein was efficiently purified by DEAE-Sephacel column 


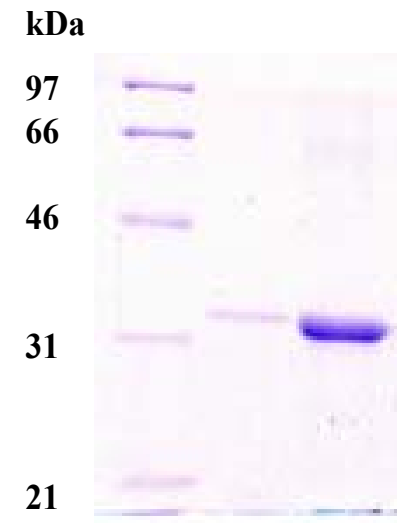

Fig. 3. SDS-PAGE analysis of tTF purification. The electrophoresis was performed on $12 \%$ polyacrylamide gels. Lane 1, molecular weight markers; Lane 2, standard tTF; Lane 3, final tTF product obtained by DEAE-Sephacel chromatography. The band of each lane at the bottom of the gel is trace of dye.

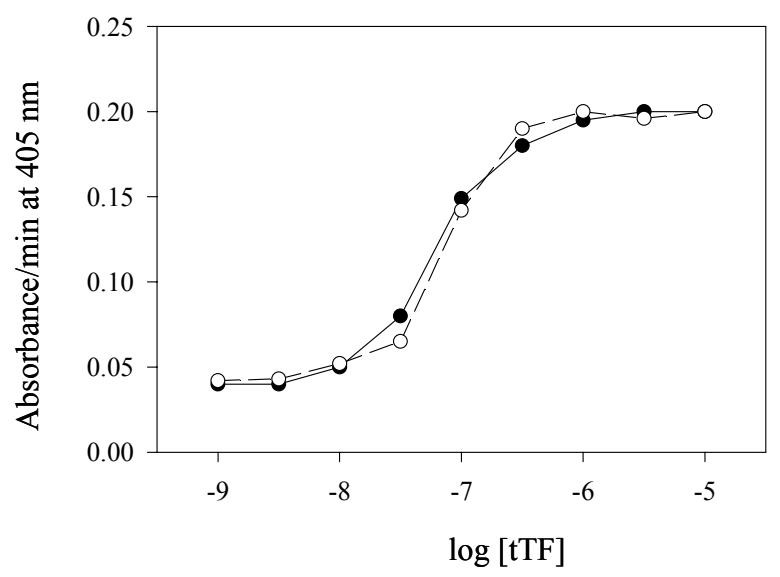

Fig. 4. Activity assay of recombinant tTF. Closed circle, tTF purified as described in the present study; Open circle, standard tTF. The $\mathrm{X}$-axis is logarithm of molarity.

chromatography and successfully refolded on the column. According to our knowledge, the tTF described here is comparable to those of the other expression systems reported in terms of expression level, purity, and biological activity. The expression system in this study has the advantage over other tTF expression system. The tTF expression level described here is one of the highest among published other tTF expression system. Our on-column refolding procedure is simple and comparable to the method published by Gao et al. [3]. However, the present purification system does not require a protease treatment and an additional chromatographic step to remove a fusion contaminant. Our expression and purification system allow a high level and quality production of $\mathrm{tTF}$, which provides a very useful alternative to conventional expression systems for the production of tTF.

\section{Acknowledgments}

This work was financially supported by the Ministry of Education, Science and Technology (MEST) and Korea Industrial Technology Foundation (KOTEF) through the Human Resource Training Project for Regional Innovation.

\section{References}

1. Bradford, M. A. 1976. Rapid and sensitive method for quantification of microgram quantities of protein utilizing the principle of protein-dye binding. Anal. Biochem. 72, 248-254.

2. Gao, B., S. Li, and P. E. Thorpe. 1998. A simple and rapid method for purifying the extracellular domain of human tissue factor. Thromb. Res. 91, 249-253.

3. Guan, M., B. Su, C. Ye, and Y. Lu. 2002. Production of extracellular domain of human tissue factor using maltose-binding protein fusion system. Protein Expr. Purif. 26, 229-234.

4. Ruf, W., M. W. Kalnik, T. Lund-Hansen, and T. S. Edgington. 1991. Characterization of factor VII association with tissue factor in solution. J. Biol. Chem. 266, 15719-15725.

5. Ruf, W., J. Shobe, S. Rao, C. D. Dickinson, and T. S. Edgington. 1999. Importance of factor VIIa Gla-domain residue Arg-36 for recognition of the macromolecular substrate factor X Gla-domain. Biochemistry 38, 1957-1966.

6. Spicer, E. K., R. Horton, L. Bloem, R. Williams, A. Guha, J. Kraus, T. C. Lin, Y. Nemerson, and W. H. Konigsberg. 1987. Isolation of cDNA clones coding for human tissue factor: primary structure of the protein and cDNA. Proc. Natl. Acad. Sci. USA 84, 5148-5152.

7. Stone, M. J., W. Ruf, D. J. Miles, T. S. Edgington, and P. E. Wright. 1995. Recombinant soluble human tissue factor secreted by Saccharomyces cerevisiae and refolded from Escherichia coli inclusion bodies: glycosylation of mutants, activity and physical characterization. Biochem. J. 310, 605-614.

8. Waxman, E., J. B. A. Ross, T. M. Laue, A. Guha, S. V. Thiruvikraman, T. C. Lin, W. H. Konigsberg, and Y. Nemerson. 1992. Tissue factor and its extracellular domain: The relationship between intermolecular association with factor VIIa and enzymatic activity of the complex. Biochemistry 31, 3998-4003. 
초록 : 인간조직인자 세포외 부분의 효과적인 제조 방법

유환구 · 박양진 · 이우일 ${ }^{1}$ *

(건양대학교 화학과, ${ }^{1}$ 건양대학교 제약공학과)

인간조직인자는 혈액응고인자 factor VII 과 복합체를 형성하며 연속적인 혈액응고 연쇄반응을 촉매하는 효소 활성체이다. 복합체 형성에 필수적인 이 조직인자의 세포 외 부분이, 기존의 융합 단백질 및 히스티딘 말단이 없는 새로운 발현 벡터에 의해 대장균 내에서 과량 발현 되었다. 봉입체 형태로 발현된 재조합 인간조직인자는 DEAE-Sephacel 크로마토그라피 기술을 적용하여 분리, 정제 및 구조적 복원이 동시에 시도 되었다. 정제된 재조합 단백질은 SDS-PAGE 분석에서 순수한 형태로 나타났으며, 생물학적 활성도 또한 기존의 조직인자와 거의 동등함을 보였다. 본 연구의 발현 및 정제 시스템은 이전의 보고에서 보여진 방법들에 비해 단백질 분해효소를 사용하지 않아 추가적인 크로마토그라피 과정이 필요 없어 좀 더 효율적이기 때문에 기존의 발현 시스템에 대해 대체할 수 있는 매우 유용한 방법으로 제공된다. 